IRSTI 21.41 .31

\author{
${ }^{1 *}$ T.T. Aimukhambetov, ${ }^{2}$ N.L. Seitakhmetova, ${ }^{1}$ Sh.S. Rysbekova \\ ${ }^{1}$ Al-Farabi Kazakh national university, \\ Kazakhstan, Almaty \\ ${ }^{2}$ Institute for Philosophy, Political Science and Religious Studies \\ *E-mail: timnesh@mail.ru
}

\title{
EUROPEAN AND AMERICAN MODELS OF STATE-CONFESSIONAL RELATIONS: RELIGIOUS ANALYSIS
}

In this article the authors have done work on the analysis of the European and American model of stateconfessional relations. One of the problems associated with the activities of public authorities in relation to religion and religious organizations of modern states is the problem of politico-legal realization of the secular state. The problem of objective definition of religion and confession in the rule of law requires special attention here. Despite the secularization of state and religious institutions, "the religious factor influences the economy, politics - and the state and society, and the interethnic relations, the family, to the cultural sphere through the activities of believing individuals, groups, and organizations in these areas." Thus, there is a certain reproduction of religious relations on the background of social relations.

Key words: state, religion, religion, Europe, America.

\section{Т.Т. Аймухамбетов, Н.А. Сейтахметова, Ш.С. Рысбекова Мемлекеттік-конфессиямық қатынастардың еуропалық және американдық моделі: дінтанулық талдау}

Бұл автордың мақаласында мемлекеттік-конфессиялық қарым-қатынастардың еуропалық және америкалық моделін талдау бойынша жұмыстар атқары^ды. Аін мен қазіргі заманғы мемлекеттердің діни ұйымдары мемлекеттік билік органдардыңқызметіне қатыстыпроблемалардың біріне байланысты, зайырлы мемлекеттің саяси-құқықтық проблемасы болып табылады. Мұнда мемлекеттік құқықтық конфессиялармен және діни проблемаларға объективті анықтауерекше назар аударуды талап етеді. Мемлекеттік әрі діни институттардың ықпалының азаюына қарамастан «діни факторлар экономикаға, политикаға, сонымен қатар мемлекеттің өзіне, қоғам мен халықаралық, қарым-қатынастарға, отбасы мен мәдениет салаларына дінге сенуші индивидтер мен топтар, осы сала ұйымдарының жұмысы арқылы өз ықпалын тигізуде». Сол себепті діни қарым-қатынастардың кейбір көріністерінің қайталануы қоғамдық қарым-қатынастар аясында болып жатыр.

Түйін сөздер: мемлекет, конфессия, Аінтану, Европа, Америка.

\section{Т.Т. Аймухамбетов, Н.А. Сейтахметова, Ш.С. Рысбекова \\ Европейские и американские модели государственно-конфессиональных отношений: религиоведческий анализ}

В данной статье авторами проделана работа по анализуевропейской и американской моделей государственно-конфессиональных отношений. ОАной из проблем, связанных с деятельностью органов государственной власти в отношении религии и религиозных организаций современных государств, является проблема политико-правовой реализации светскости государства. Особого внимания зАесь требует проблема объективного определения религии и конфессии в правовом государстве. Несмотря на секуляризацию государственного и религиозного институтов, все же «религиозный фактор влияет на экономику, политику, соответственно и на само государство и общество, - межнациональные отношения, семью, на область культуры через деятельность верующих индивидов, групп, организаций в этих областях». Тем самым происходит некое воспроизведение религиозных отношений на фоне общественных отношений.

Ключевые слова:государство, конфессия, религия, Европа, Америка. 
Speaking about the fact that practically every modern state has a constitution, and in its turn the greater part of which recognizes itself as secular, which is also indicated in the constitutions of these countries, it is necessary to bear in mind that the state cannot be removed from the religious institution. Secularism, as we know, means that no religion is a state official other or official, yet this means that the state is suspended from religious relations. This can be understood on the basis that the legal, secular state of religious associations is separated from state power.

Such normative legal principles as: secularism of the state, freedom of conscience and religious beliefs, equality of rights and freedoms of a citizen regardless of religious affiliation means that relations between the state and confessions are declared as a legal basis and constitutionally fixed.

Ideally, a secular state, in fact, does not have to erect a particular religion to the status of a state or official, and all the more, it should not be recognized as binding on all. However, in today's world, among democratic countries, there is often a case when a specific role of a religion is legislatively recognized, arguing usually its importance in the history of the state, the people and society.In spite of this, such states are still considered secular states, since the recognition of the role and significance of a particular religion proceeds along with the general democratic principles on the equality of all before the law and freedom of religion, including noninterference of the state in the affairs of the church and secular education. A vivid example is the Constitution of Greece, where in Art. 3 fixed:

The predominant religion in Greece is the religion of the Eastern Orthodox Church of Christ. The Orthodox Church of Greece, recognizing as its head our Lord Jesus Christ, is inextricably linked in its dogmas with the Great Constantinople Church and with every other single Church of Christ, steadfastly observes, like them, the holy apostolic and conciliar canons of sacred traditions. It is autocephalous and is administered by the Holy Synod of bishops who are in the church service and elected by them by the Permanent Holy Synod which is created in accordance with the procedure determined by the charter of the Church, in accordance with the provisions of the Patriarchal volume of June 29, 1850 and the Synod Act of September 4, 1928 [1].

However, Art. 13 of the Greek Constitution fix the freedom of any known religion. Permits the implementation of unhindered administration of religious rites under the protection of the law. Except for religious rituals that offend public order or morals, it is not allowed. And the same article prohibits proselytizing.
If we consider the performance of secularism on the example of the Federal Republic of Germany, you can see that, in paragraph 1 of Art. 4 of the Fundamental Law of Germany (Grundgesetz fur die Budesrepublik Deutschland) states "Freedom of religion, conscience and freedom to proclaim religious and ideological views are inviolable." In the opinion of VP Zerusalimsky "at the level of constitutional provisions, - in Germany, - wide tolerance is declared and, in fact, the separation of church and state." At the same time, the preamble proclaims that the German people adopted the Basic Law "conscious of their responsibility before God and people," here we see a certain religiousness of German society.

Several other European states, not endowing any religion with special preferences, refer to their idea of God in the preambles of their constitutions. The Albanian Constitution was adopted "... with faith in God and (or) other comprehensive values". The Constitution of Ireland on its adoption says: "In the name of the Holy Trinity, from which all the authorities come and to which, as our last hope, all the actions of man and state should be directed, we, the people, Eire, humbly accepting all our duties Before our Holy Lord Jesus Christ, who supported our fathers in so many trials ... ". The preamble of the Constitution of Switzerland begins with the words: "In the name of Almighty God! The Swiss people and the cantons, feeling responsibility before creation ... ".

Among other things, Germany is characterized by close cooperation with the churches. This state of affairs, according to VP. Jerusalem, lawyers justify that "the state cannot be made indifferent to the values and moral orientations in society - then he concludes that - the established system of agreement between him and the churches (so-called" state and church right"), is nothing but a distinctive feature of German society and is a form of cooperation [2]. It should be noted that, despite the freedom of religion, prescribed in the basic law, the Lutheran Church and the Roman Catholic Church are the dominant ones in the FRG. As a consequence, in Germany "the dominant Christian churches recognized their representation in the governing bodies of radio and television companies of public and public status - as well as they are enshrined" the right to participate in the examination of films for hire, the organization of the teaching of religion in schools. "One of the diverse forms of fruitful cooperation between church and state is cooperation in the "social sphere (in health care, education)." It should be borne in mind that the active participation of religious institutions in legal relations with the state and society gives 
them the right to levy church tax from the lands that are in their vision. Such rights are enshrined in the German Constitution of August 11, 1919, which is an integral part of the basic law of Germany. So in Art. 137 of the German Constitution of 1919 established:

(5) Religious societies remain public-law corporations, since they have already been such. Other religious societies should be granted, at their request, the same rights, if by their structure and number of members they give a guarantee of a long existence. If several such public-law societies are united in an alliance, then such a union is also a public-legal corporation.

(6) Religious societies that are public corporations have the right to levy taxes on the basis of civil tax lists in accordance with the provisions of the law of the land.

The role of the church in the life of German society is reinforced not only by the historical prerequisites for the existence of the Lutheran and Roman Catholic churches, but also by the political structure of the Federal Republic of Germany. So the interests of the clergy in the Bundestag (the parliament of Germany) are lobbied by a joint faction of two Christian parties: the Christian Democratic Union of Germany and the Christian Social Union of Bavaria. Thus, the union of the CDU / CSU is the strongest party in the FRG, which in fact is the main basis for supporting the clergy of the dominant churches in public administration [3].

It can be concluded that the division between the churches and the state in the FRG is not complete; moreover, the clergy occupies a significant place both in the political arena and in social and economic relations in Germany. Thus, the Federal Republic of Germany, on the one hand, "occupies a peculiar intermediate position between the United States and France," where the constitution establishes the complete separation of the church from the state, on the other hand - "Britain, Sweden, or Russia, where the" state church "is in a privileged position ".

A similar relationship between religion and state is in the Finnish Republic. So in the Constitution of Finland the evangelical-Lutheran church is fixed. Relations between the church and the state are regulated by special agreements, and the activities of the churches themselves are regulated by special legislation. But in Article 76 of the Constitution of Finland, there is a reservation specifically that "the regulations on the organization of the Evangelical Lutheran Church and its management are contained in the Law on the Church." Actually, the law regulates the internal structure of the church, regulations on the activities of the church and religious institutions, the rights and duties of bishops, bishops' meetings, etc. Along with the municipal tax, a church tax is levied on citizens. Nevertheless, the current legislation guarantees citizens freedom of religion.

In the primary and secondary classes, ethics and religion are taught. In an educational institution, the teaching of religion is conducted in accordance with a large number of pupils of one or another religious affiliation. In the event that at least three students of another religious affiliation are recruited, they are offered appropriate training.

Currently, about $85 \%$ of the population professes Lutheranism in Finland, of whom less than 10\% participate in church services, and just over $50 \%$ pray. In second place is the Orthodox Church, which is professed by about $1.1 \%$ [4]. Also no more than the numbers of citizens profess: Islam, Judaism, Catholicism, Pentecostals meet and Jehovah's Witnesses.

Within the framework of the relationship between religion and the state, the interests of the Republic of France are interesting, in the constitution of which the motto "Freedom, Equality, Brotherhood" is fixed. According to Article 1 of the Constitution: France is an indivisible, secular, social, democratic Republic. It ensures equality before the law for all citizens without distinction as to origin, race or religion. She claims all religions. Its device is decentralized. It should be stipulated that the principle of secularism was fixed still in the law of December 9, 1905: the Republic does not recognize, pay or subsidize any religion. Accordingly, from January 1, after the entry into force of this law, all expenses related to the religion should be removed from the state budget, departments and communes. However, budgetary services may include priest services and the provision of free religious practice in public institutions, such as schools, colleges, hospitals, shelters, and prisons. Abolished, state institutions of religion, taking into account the provisions contained in Article 3.

Public schools are completely secular, this situation was strengthened with the adoption in 2004 of a law prohibiting staff and students from "wearing religious symbols in public schools." "Religious organizations in France are not required to register if they do not seek a preferential tax status." In addition, despite the fact that the law applies the concept of "Cult", which includes "The Order of the Solar Temple, the Church of Scientology, and Jehovah's Witnesses", nevertheless this does not lead to a restriction of the activities of these organizations. According to A. Mitrofanova. "The French system, in a sense, is an analogue of the British, although it sounds paradoxical. Laicism 
is seen as a kind of civil religion (republican faith): it is not just a political principle, but an ideology that itself takes on religious forms".

In addition, in September 2011, the law prohibits praying on the streets. So the ex-Minister of the Interior of the French Republic Claude Guén stated: "With prayers on the streets it is necessary to finish, because this practice touches the feelings of many of my compatriots, shocked by the fact that the public space is given for a religious rite." However, on September 14, 2011, with the Muslim associations, the agreement of the XVIII district of the Paris quarter of Goutte d'Or was signed, thus, the believing Muslims who had previously salted in the streets of Mir and Polonso were given permission to gather for prayer in the nearby buildings. So the state allocated a space of 2 thousand square meters for rent, for a period of 3 years, at a fixed price of 30 thousand euros per year. Here the question arises: is this interference of the state in the private life of citizens? And at the same time restriction of freedom?

The analysis of normative legal acts of the Republic of France has revealed the following points that answer the questions posed. In France, it is commonly believed that "the law protects people from action that may cause damage to society." In turn, freedom is treated, as a rule, or due, and infringements of freedom are a kind of protests. Accordingly, any restriction of freedom must be regulated by law, while "based on the principles of proportionality and necessity." However, the Republic of France does not have a law on blasphemy, as well as on homosexuality. "The last law on homosexuality was abolished in 1971. In 2013, homosexuals in France were given the right to officially marry and raise children. "

Thus, in the French Republic, the process of the complete separation of the state and the church is most pronounced and originates from the law of 1905. The constitution of France prescribed the principle of freedom of conscience; in addition, the state does not support or fund any religious organization. "Religion is a private matter of French citizens (these rules do not apply to the territories of Alsace and Lorraine)." Nevertheless, in France there are rudiments of cooperation between the state and religious organizations. Thus, for example, the state reimburses expenses that include services of a priest, and at the same time ensuring the possibility of professing religion in state institutions (schools, colleges, hospitals, shelters and prisons). For various reasons, religious organizations may be granted benefits [5].

In addition to the states considered above, the legislation of more than thirty Western countries, both Western European countries and both American continents, was analyzed. Thus, it was revealed that the legal status of the church is hushed up in at least three of the countries that have come under investigation - Bosnia and Herzegovina, Hungary and Venezuela. In the meantime, the secularization of the church and the state is legislated in the constitutions of nine states. At the same time, seven of them use the wording that the Church or the religious community is separated from the state: Bulgaria, Latvia, Macedonia, Portugal, Ukraine, Croatia and Yugoslavia. While the constitution of Slovenia stipulates the separation of the state and the church from each other, and in the main law of Moldova the phrase "from the state is separated religion" is applied.

As we have already explained, the concept of "dominant religion" is present only in the Constitution of Greece, including the form of state religion enshrined in the basic laws of eight states: England in the United Kingdom, Denmark, Costa Rica, Liechtenstein, Malta, Monaco, Norway and Scotland In the United Kingdom. Moreover, religion enjoys support and has great influence in Poland. The wording "traditional religion" is used in legislation: Andorra, Bulgaria, and Lithuania.

The privileged position of one religion or another, or the official status of the church, is absent in the eleven countries of the Republic of Albania, Belarus, Ireland in the United Kingdom, the Italian Republic, the Kingdom of Spain, the Republic of Macedonia, Lithuania, Slovakia, USA, Ukraine, in Wales as part of the United Kingdom And Estonia.

Table 1 - the position of the church and religious organizations according to the legislation of the European and American countries

\begin{tabular}{|l|l|}
\hline \multicolumn{1}{|c|}{ The wording according to the legislation } & \multicolumn{1}{c|}{ State } \\
\hline The church is a legal entity or has the rights of a legal entity & Albania, Andorra, Brazil, Guatemala, Germany, Italy and Lithuania \\
\hline The Church is subject to the general laws of the state & Austria, Andorra, Brazil, Moldova and Croatia \\
\hline Relations between the state and the church are regulated by a special law & Albania, Belarus, Italy, Colombia, Luxembourg, Poland \\
\hline The state does not interfere in the activities of religious associations & Slovakia, France, Czech Republic \\
\hline
\end{tabular}




\begin{tabular}{|l|l|}
\hline \multicolumn{2}{l}{ Table 1} \\
\hline The state patronizes the activities of the church organization & Croatia \\
\hline Servants of all religions are under the supervision of the state & Greece \\
\hline $\begin{array}{l}\text { Only the right of the church to movable and immovable } \\
\text { property is fixed }\end{array}$ & Austria, Poland, Bolivia, Ireland, Cyprus, Liechtenstein \\
\hline The property of the church belongs to the state & Mexico \\
\hline
\end{tabular}

It is interesting that the principle of «freedom of conscience» is not provided for approximately in the analyzed states. Thus, one way or another, freedom of belief is limited in the states listed in Table 2 .

Table 2 - Restrictions on freedom of conscience, religion, worship in European and American States

\begin{tabular}{|c|c|}
\hline Types of restrictions & States \\
\hline $\begin{array}{l}\text { Contradiction to legislation or public order, the principles of } \\
\text { morality and public morals }\end{array}$ & $\begin{array}{l}\text { Austria, Belarus, Belgium, Bulgaria, Brazil, Italy, Poland, Slovakia, } \\
\text { France, Czech Republic, Estonia, Colombia, Luxembourg, Ukraine, } \\
\text { Estonia, Cyprus, Netherlands, Germany, Finland }\end{array}$ \\
\hline Threat to health or life & $\begin{array}{l}\text { Belarus, Bulgaria, Cyprus, Lithuania, Slovakia, Czech } \\
\text { Republic, Estonia, Ukraine, Poland }\end{array}$ \\
\hline Contradiction to the rights and freedoms of others & $\begin{array}{l}\text { Belarus, Bulgaria, Cyprus, Lithuania, Slovakia, Czech } \\
\text { Republic, France, Poland, Ukraine }\end{array}$ \\
\hline $\begin{array}{l}\text { Temporary restriction in the period of martial law or in case of } \\
\text { immediate danger threatening the constitutional order }\end{array}$ & Lithuania, Poland, Cyprus \\
\hline The use of religious organizations for political purposes & Bulgaria, Colombia, Costa Rica \\
\hline Restrictions in the field of upbringing or education & Mexico, Slovenia \\
\hline Financing of religious organizations & Honduras, Poland, Finland \\
\hline Prohibition of proselytism & Greece \\
\hline $\begin{array}{l}\text { Participation of the state in appointment and admission to the } \\
\text { post of heads of religious cults }\end{array}$ & Luxembourg \\
\hline $\begin{array}{l}\text { Restriction of places of committing public acts of religious } \\
\text { worship }\end{array}$ & $\begin{array}{l}\text { Austria, Belorussia, Belgium, Bulgaria, Brazil, Greece, } \\
\text { Poland, Slovakia, France, Czech Republic, Estonia, Colombia, } \\
\text { Luxembourg, Ukraine, Cyprus, Netherlands, Germany, Finland, } \\
\text { Mexico, Lithuania, Ireland, Iceland, Spain, Italy }\end{array}$ \\
\hline Establishment of a religious qualification for the head of state & Great Britain, Denmark and Norway \\
\hline Limitation of ownership and distribution of property & Austria, Ireland, Cyprus, Lithuania, Liechtenstein, Poland \\
\hline Transfer of cemeteries to the government & Brazil, Nicaragua \\
\hline
\end{tabular}

Here it is necessary to pay attention to the fact that often the legislative consolidation of the position of the church and religious organizations in the political system of the European states, including the mechanism of interaction, is most often not connected with the confessional features of countries, moreover religious minorities of any religion may not take into account.
Increased religiosity among Western countries, represent the overwhelming majority of the states of Central and South America, the constitution, regulate and consolidate the issues of faith. The main law of the Argentine Republic states: «Trusting in the protection of God is the source of everything reasonable and just, we prescribe, proclaim and establish this Constitution of the Argentine Nation.» 
The Constitution of Brazil says «promulgate under the protection of God ...» While the Constitution of the Republic of El Salvador, for example, states: «We, the representatives of the Salvadoran people gathered in the constituent assembly, based on our faith in God ...» Another of the Latin American states, the Republic of Paraguay adopted its Basic Law «through its legitimate representatives, gathered in the national constituent assembly, trusting in God ...> In the Preamble of the Ecuadorian Constitution, the theme of the Divine is also raised: «The Republic of Ecuador on behalf of its people calls for protection God ...»

Despite the religious bias of the Constitutions of the American States, there is a division between the state-power structures and the church. Only the Constitution of Costa Rica recognizes the Catholic religion as official. And if in Finland the Lutheran church is included in the program of education in junior and middle classes, then in the basic law of the Republic of Panama, the teaching of Catholic religion in the school passes on the principle of voluntariness [4].

The conducted research allows to say that the regulation of political and religious relations in the Western countries is very diverse. There may be similarities in the legal respect, as well as the distinctive features peculiar to one or another state.

Summarizing this section, it can be noted that the European constitutions, in the implementation of democratic principles and secularism of the state, have a wide range of various ways to regulate the relationship of state and political institutions with religious institutions and, in general, attitude to faith, the church.

In some Western states, religion will have an official or dominant status. This, in the UK, at the legislative level: "On the royal throne of Great Britain, all subsequent time, with his or her accession to the throne, must swear an oath and a written commitment that he will unswervingly support and protect the above-stated establishment of a true Protestant religion and the order of government, worship, deanery of the rights and privileges of this church.»

For example, the Kingdom of Norway, in accordance with Article 2 of the Constitution, declares: "The Evangelical Lutheran religion is the official state religion. The residents who live in it must educate their children in it. «In addition, according to Norwegian law, the king at least half of the ministers must profess Lutheranism [3].

As already explained under the Constitution of the Republic of Greece, not only religious preferences are fixed, but also elements of the cult: "The religion of the Eastern Orthodox Church of Christ is the ruling religion in Greece.» The most radical of all analyzed legislations of the European states is the formulation of the official status of the church in the Republic of Malta: "The religion of Malta is the Roman Catholic apostolic religion. The organs of the Roman Catholic Apostolic Church are obliged and have the right to teach which principles are just and which are wrong.»

Most of the Western countries of Europe and America are states with a dominant faith in society. So the number of followers of Catholicism exceeds from 70\% (the Republic of Austria, the Kingdom of Spain, the United Mexican States) more than 95\% (Argentine Republic, Republic of Malta, Italy). On the second place among the Western countries are the countries where the majority of the population profess different trends of Protestantism, the Lutheran church from $70 \%$ (the Republic of Finland, the Kingdom of Sweden) and more than $80 \%$ (the Kingdom of Denmark). Separately it is necessary to allocate the Great Britain where official religion is Church of England, however, as well as in Canada, the Netherlands, the USA, Germany the number of parishioners is not the absolute majority [1].

Thus, among Western countries, both states with official religion, and states where a particular confession has a dominant, in terms of the number of professors, position, render, at first sight, seemingly unseen political support for religion traditional for European and American society. Possible oppression of religion is the number of followers who are significantly less, which is not expressed in the open restriction of freedom of conscience. A vivid example of this can be the change from the beginning of 2000. Legislation of European countries, including the United States.

So, the law adopted in France in 2004, restricting the rights of citizens to perform religious rituals on the street, primarily concerned Muslims, whose number in France is less than 5 percent. The privileged position of the church in the FRG, which gives the church the opportunity to participate in the daily life of the Germans, including in political life; The educational program of the Republic of Finland, according to which the Lutheran religion is taught in schools, other moments have, first of all, political preconditions, against the backdrop of unfolding in the territory of Muslim countries, anti-terrorist activities. 
T.T. Aimukhambetov et al.

\section{References}

1 Printsipy demokratii v Islame// Novoe delo. - 16.05.2003. - № 20.

2 Miroshnikova E. Gosudarstvenno-tserkovnye otnosheniya v Germanii // Religia I pravo. - 1988. - №1-2. - S. 45-47.

3 Zakon «O religioznoi deyatelnosti i religioznykh obedeneniyakh». - Almaty: «Yurist», 2013.

4 http:/www.neonomad.kz/styleneonomad/moda/index.php?ELEMENT_ID=3842.

5 Obshchestvennoe obedinenie «Izgi amal». Manifest Islamskoi reformatsii. TOO «Mag-Nur». 2009 g. - $104 \mathrm{~s}$.

6 Orynbekov M.S. Genezis religioznosti v Kazakhstane. - Almaty, 2013. 